\title{
Relationships Among Attitude, Corporate Image, and Purchase Behavior in Korean Running Event
}

\author{
Jaeyoon Kwon ${ }^{1} \&$ Taerin Chung $^{2}$ \\ ${ }^{1}$ Global Center for Arts and Culture Education, Sangmyung University, Seoul, Republic of Korea \\ ${ }^{2}$ Department of Life Sports Education, Kongju National University, Kongju, Republic of Korea \\ Correspondence: Taerin Chung, Department of Life Sports Education, Kongju National University, Kongju, \\ Republic of Korea.
}

$\begin{array}{lc}\text { Received: February 5, } 2018 \quad \text { Accepted: February 21, } 2018 \quad \text { Online Published: February 27, } 2018 \\ \text { doi:10.5539/ijms.v10n1p82 } & \text { URL: https://doi.org/10.5539/ijms.v10n1p82 }\end{array}$

\begin{abstract}
The purpose of this study was to verify the relationships among attitude, corporation image, and purchase behavior in Korean running event. Through this study, running event of Korea may attempt to develop sports event and sports industry infrastructure. To achieve the goal of this study, 432 surveys were collected form male and female adults who planned to participate in Korean running event in October 2016 to February 2017 were delineated as the study population. A convenient, non-random sampling method was used to select participants. After examining the correlation among attitude, corporation image, and purchase behavior, the relationships among the three variables was assessed through multiple linear regression analysis. The results of this were as follows. First, regarding sub-factors of event attitude and brand attitude had positive effects on corporate image. Second, the sub-factors of event attitude and brand attitude had positive effects on purchase behavior. Third, the sub-factor of corporate social responsibility image had positive effects on purchase behavior, and good image of corporation was statistically significant.
\end{abstract}

Keywords: attitude, corporate image, purchase behavior, Korean running event

\section{Introduction}

In 2017, the number of Korean people that run for exercise was estimated to be approximately six million. There are about 400 running events each year in the country. It is estimated that many more events will be held in the future, from large to small competitions, as more people become more serious about their well-being and about living a healthier lifestyle. At present, running is the most popular leisurely activity, and more sports brand companies prefer hosting and promoting running events, which can also improve their positive corporate image. Running events at present in Korea include Nike's We Run, Adidas' My Run, the New Balance's Color Run, Asics' Cool Run, and the Reebok's Spartan Race. Sports brand companies finance and hold these races because they perceive them as direct interactive communications to promote corporate involvement in these events, which is believed to generate increased consumer awareness of their brands, a chance to initiate the marketing halo effect and, therefore, gain long-term positive effects such as customer loyalty across their product offerings. The title sponsorship program associated with sporting events has the advantage of enhancing corporate sales (Marshall \& Cook, 1992) and enhancing corporate image (Ko, Chang, Park, \& Herbst, 2017), making it easier to reach the public. The most important factor influencing the formation of corporate image is its marketing image, which determines the behavior and attitude of companies and products through corporate image (Burnett \& Hutton, 2007; Cole \& Illum, 2006). In particular, the title sponsor is one of the most important sponsorship methods (Laband, Seals, \& Wibrandt, 2015) as it cans double the sponsor's benefits by having the name of the event connected to a particular corporation. Sponsorship programs related to sporting events improve the company's sales (Funk, Mahony, Nakazawa, \& Hirakawa, 2001; Hightower, Brady, \& Baker, 2002). The overall image formation of a company is very important as it determines consumer behaviors and attitudes about products.

A running event hosted by a sports company will involve a variety of people from various levels of experience who are provided with information from the company such as new product tastings, new product experiences, related brochures, videos, and services (Gwinner \& Swanson, 2003; Wohlfeil \& Whelan, 2006). In addition, it is meaningful to discern a causal relationship between the attitude of potential customers and their purchasing 
behavior sand the corporate image. This is important information that provides the evaluation criteria for determining whether a company should plan on holding the designated sporting event more than once.

Research on sports event sponsorship since the 1990s has been increasing steadily. Results generally show that corporate sponsorship activities have a positive effect on corporate image, image enhancement, brand attitude, and product purchasing (Du, Bhattacharya, \& Sen, 2010; Javalgi, Traylor, Gross, \& Lampman, 1994; Nichollas, Roslow, \& Dublish, 1999). However, most studies on sports sponsorship have been focused on professional sports. Research on general population participatory sporting events, such as running events, is relatively inadequate.

Participation in watching versus participation in activities can show a significant difference in the behavioral

Characteristics and participant attributes. Therefore, such research promises revealing outcomes that are different from research on spectacular sports events or events only for professional athletes (Gratton, Shibli, \& Coleman, 2006). In Korea, sports sponsorship participation has increased in recent years in many sporting event venues. However, there is a lack of research on sport sponsorship for public participatory sports to determine the number of events. Participant awareness of such running events is representative of participatory sports events in Korea.

The purpose of this study is to investigate the relationship between consumer attitudes toward titled sponsorship for sporting events and the sense of corporate image and purchasing intention of competitors in running contests sponsored by sports companies. The research model set up to achieve the research objective is shown in Figure 1.

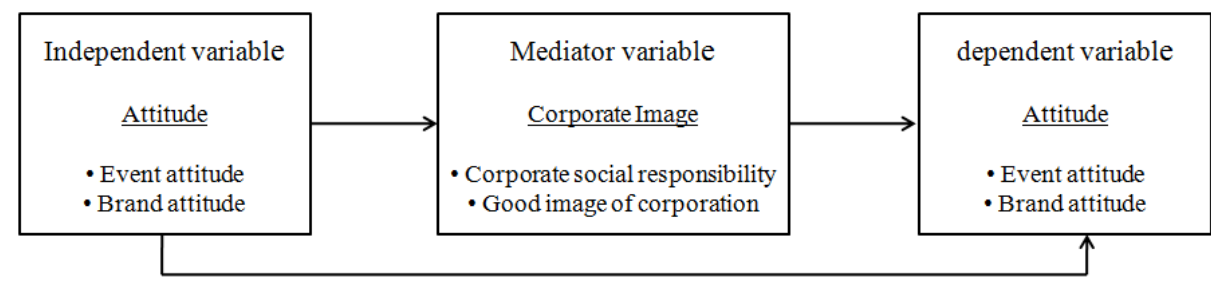

Figure 1. Framework of the study

\section{Literature Review}

\subsection{Participating Sport Events: Running}

In recent years, consumer interest and participation has changed regarding sporting events, and companies are actively using sporting events to promote their businesses because participatory sports events for the general public are more dynamic marketing factors than events meant only for public viewing. Participatory events are more effective as marketing means because of the higher involvement and dynamic when consumers play an active part in the event (Brodie, Ilic, Juric, \& Hollebeek, 2013). Participation sporting events are favored by companies because they have the advantage of being able to achieve integrated marketing communication. In addition to the positive effects of raising awareness, improving corporate image, and increasing profits by sponsoring sports events, there are additional social returns as the public perceives that corporations are supporting their personal goals of improving personal well-being. In other words, there is significant return on investment for money spent on advertising and publicity through various media platforms such as stadium signs, banners, electronic billboards, and various promotional materials designed to gain consumer participation in events like running competitions (Fourie \& Santana-Gallego, 2011).

Running events are becoming increasingly popular because participations requires no special skills, making it easy to participate, and because of the wide-spread advertising for the events. Therefore, interest and participation in running events by media, corporations, and local governments are also increasing. More and more participatory running events are being made available to the public as their involvement continues to grow, making two-way communication with companies more possible. These are new opportunities and advantages for improving corporate images (Meenaghan, 2001), and consumer attitudes toward sponsoring companies are driving increased corporate sponsorship for running events, making active research essential to understanding these trends. 


\subsection{Suitability of Sponsored Event and Brand Attitude}

According to Schema's theory, consumers memorize information about products as an independent concept rather than memorizing it as a composite composed of various concepts (Cakici \& Shukla, 2017). In other words, when a brand sponsors a sports event, the consumer connects their memories of the concepts related to the brand and the event, activating related concepts between the two objects. In this case, the more consistent the characteristics of the two objects, the easier it becomes to transfer knowledge and emotion from one object to another, and the positive attitudes increase through persuasion (Bettina, Michael, Angela, Clinton, \& Cassandra, 2006). In this way, if the transfer of knowledge or emotion from two objects to another is easy, the stronger the connection between the sponsor brand and the sporting event, the more positive attitude the sponsor has to the brand. In contrast, when the suitability of the event and the sponsor brand is low, consumer doubt regarding the sponsor's motive is high, which eventually evokes a negative attitude toward the sponsor's brand.

\subsection{Sports Events, Image Transfer, and Purchasing Behavior}

The theoretical background for the effectiveness of sponsorship can be found in the image transfer hypothesis of Smith (2004). They explained that when a specific brand is associated with a sponsored sporting event, associations of the event are linked to the brands sponsoring the event. The image transfer model is verified practically through sponsorship-related research. When consumers are exposed to sports events and sponsorships, they feel the relationship between the sponsoring brands and the events. Eventually, the atmosphere and images of the event are transferred to the brand image of the company (Cretu \& Brodie, 2007). In particular, the greater the similarity of the images of the activities of the sports events and sponsoring brands, the greater are the chances of improvement of the attitudes and purchasing behaviors of sponsor brands (Rowley \& Williams, 2008).

\subsection{Sport Event, Image Transfer, and Purchase Behavior}

The theoretical background for the effectiveness of sponsorship can be found in the image transfer hypothesis of Chien, Cornwell, \& Pappu (2011). They explain that when a specific brand is associated with a sport event sponsored event, associations of sport events are linked to the brands sponsoring the event. The image transfer model is practically verified through sponsorship related research. When consumers are exposed to sport events and sponsorships, they feel the relationship between sponsor brands and events. Eventually, the atmosphere and images of the event are transferred to the brand image of the company (Cretu \& Brodie, 2007). In particular, the greater the similarity of image between sport events and sponsor brands, the more attitude and purchase behavior of sponsor brands are improved (Rowley \& Williams, 2008).

\section{Method}

\subsection{Participants and Procedure}

Table 1. Demographic characteristics of participants

\begin{tabular}{llll}
\hline Characteristics & Classification & $\mathrm{N}$ & $\%$ \\
\hline Age & 20 's & 72 & 16.6 \\
& 30 's & 213 & 49.4 \\
& 40 's & 100 & 23.2 \\
\multirow{3}{*}{ Participation event } & Over 50 & 47 & 10.8 \\
& Half marathon & 73 & 16.9 \\
\multirow{2}{*}{ Information source } & $5 \mathrm{~km}$ & 138 & 31.9 \\
& $10 \mathrm{~km}$ & 221 & 51.2 \\
& Newspaper or Magazine & 119 & 27.5 \\
\multirow{5}{*}{ Sponsor's brand recognition } & TV or Internet & 185 & 42.9 \\
& Friend or colleagues & 33 & 7.7 \\
Experience of purchasing products & SNS & 95 & 21.9 \\
& I knew & 356 & 82.4 \\
& L did not know & 76 & 17.6 \\
Total & 2-4 times & 93 & 21.5 \\
& Over 4 times & 156 & 36.1 \\
& & 183 & 42.4 \\
\end{tabular}

To examine the relationships among attitudes toward the event, brand, corporate image, and purchase behavior in Korea running events, male and female adults who planned to participate in an event in 2015 were delineated as the study population. A convenience, non-random sampling method was used to select participants. In total, 445 questionnaires were distributed, and of these, 13 were eliminated based on a lack of information and low validity. 
Thus, data in 432 questionnaires were analyzed. A summary of the general characteristics of the study is shown in Table 1.

\subsection{Measurements}

The primary research method adopted in this study was the questionnaire method (survey). Table 1 outlines characteristics of the questionnaire. Questionnaire items included 5 questions pertaining to demographic characteristics, 6 focusing on event attitude and brand attitude, 8 on corporate social responsibility (CSR) image and good image of corporation, and 3 on purchase behavior.

Event and brand attitudes scale used in this study was modified from Stipp \& Schiavone (1996)'s original event attitude scale, which was created and modified by Roy \& Cornwell (2004), corporate image scale used in this study was modified from Nguyen \& Leblanc (2001), and translated and modified for use in Korea. Purchase behavior scale used in this study was modified from Gedenk \& Neslin (2000), Sharma \& Patterson (1999). Questionnaires were measured on a five-point Likert scale ranging from "Strongly disagree" (1) to "Strongly agree" (5).

\subsection{Validity and Reliability Tests}

The validity and reliability of the study were verified through an expert discussion on the questionnaire items. To access the questionnaire's content validity, 100 questionnaires were distributed. Of these, 5 were eliminated because of a lack of information; therefore, 95 were used in the preliminary research. Despite that the test value in this study was verified in earlier work, it was re-verified to ensure a better result.

Regarding construct validity and to verify questionnaire reliability, and exploratory factor analysis and reliability analysis were conducted. With principal factor analysis for factor extraction, the varimax rotation method was based on an eigenvalue of 1.0 or more, while selected items had factor values of .6 and more. To verify the reliability of the study, Cronbach's $\alpha$ coefficient was used, and to determine if internal consistency was acceptable, Bartlett's Kaiser-Meyer-Olkin (KMO) standard fit test was employed. Generally, KMO values exceeding 0.5 indicate suitable validity, while in the Bartlett case; significance levels of $\mathrm{P}$ values less than .05 signify suitable factor analysis. Table 2,3 and 4 provide the results of the exploratory factor analysis.

Table 2. Results of the validity test: attitude factors

\begin{tabular}{lll}
\hline & Event attitude & Brand attitude \\
\hline I like this sponsorship running event & $\mathbf{. 8 8 6}$ & .182 \\
The sponsorship running event is positive for me & $\mathbf{. 8 3}$ & .218 \\
I am attracted to this sponsorship running event & $\mathbf{. 8 3 6}$ & .252 \\
I like the sponsorship brand of running event & .156 & $\mathbf{. 8 5 6}$ \\
Sponsorship brand in running event is positive & .151 & $\mathbf{. 7 9 4}$ \\
Sponsorship brand in running event feel good & .381 & $\mathbf{. 7 6 8}$ \\
\hline Eigenvalue & 2.455 & 2.097 \\
\% of Variance & 40.919 & 34.958 \\
Cumulative \% & 40.919 & 75.877 \\
Cronbach's $\alpha$ & .873 & .831 \\
\hline
\end{tabular}

Note. Kaiser-Mayer-Olkin Measure $=.808 ;$ Bartlett's Test $=1094.101, \mathrm{df}=15, \mathrm{Sig}=.000$.

Table 3. Results of the validity: corporate image factors

\begin{tabular}{llc}
\hline & Corporate social responsibility image & $\begin{array}{c}\text { Good } \\
\text { corporation }\end{array}$ \\
\hline Sponsor brand are likely to have a high contribution to the community & $\mathbf{. 8 9 4}$ & .194 \\
Sponsor brand will pay attention to consumer issues and problem & $\mathbf{. 8 9 1}$ & .135 \\
Sponsor brand will pay a fair tax & $\mathbf{. 8 6 6}$ & .251 \\
Sponsor brand will have a corporate spirit of respect for humanity & $\mathbf{. 7 8 7}$ & .269 \\
Sponsor brand will have excellent management skills & .232 & .068 \\
Sponsor brand will be a company with excellent product quality & .256 & $\mathbf{. 8 4 2}$ \\
Sponsor brand are likely to grow & .178 & $\mathbf{. 7 7 1}$ \\
Sponsor brand will invest a lot in technology development & 3.408 & $\mathbf{. 7 2 6}$ \\
Eigenvalue & 37.862 & $\mathbf{. 7 0 5}$ \\
\% of Variance & 37.862 & 3.173 \\
Cumulative $\%$ & .862 & 35.256 \\
Cronbach's $\alpha$ & $\mathbf{7 3 . 1 1 8}$ \\
\hline Not Kaiser-Mayer-Olkin Measure & .837 \\
\hline
\end{tabular}

Note. Kaiser-Mayer-Olkin Measure $=.866$; Bartlett's Test $=2369.161, \mathrm{df}=36, \mathrm{Sig}=.000$ 
Table 4. Results of the validity: purchase behavior factor

\begin{tabular}{ll}
\hline & Purchase behavior \\
\hline I will purchase the products of the sponsor brand & $\mathbf{. 9 6 4}$ \\
I will be able to purchase products from sponsor brand & $\mathbf{. 9 5 3}$ \\
I am likely to purchase the products of the sponsor brand & $\mathbf{. 9 1 8}$ \\
Eigenvalue & 2.682 \\
\% of Variance & 89.396 \\
Cumulative \% & 39.396 \\
Cronbach's $\boldsymbol{\alpha}$ & .949 \\
\hline
\end{tabular}

Note. Kaiser-Mayer-Olkin Measure $=.739$; Bartlett's Test $=1114.897, \mathrm{df}=3, \mathrm{Sig}=.000$

\subsection{Data Process}

The study was conducted over a period of four months, from October 2016 to February 2017, during the training of runners aiming to participate in a running event in Seoul. Participants were asked to answer questions through a self-administration method. Of 445 questionnaires, 13 were eliminated because of a lack of responses and/or inaccurate information. The remaining 432 questionnaires were used in the statistical analysis, which was conducted using SPSS version 21.0. The analysis method was as follows. First, to assess the validity of the study, an exploratory factor analysis and confirmatory factor analysis were conducted. Second, for the general features of the study, a frequency analysis was carried out. Third, to examine the differences between attitude, corporate image and purchase behavior based on demographic characteristics, the t-test, a one-way analysis of variance, and the Scheffe method were employed as post-verification tests. Fourth, a correlation analysis was conducted for factor correlation. Last, the relationship between attitude, corporate image and purchase behavior was analyzed through multiple regression analysis.

\section{Results}

\subsection{Relationship between Attitude, Corporate Image, and Purchase Behavior}

To examine the relationship among attitude, corporate image, and purchase behavior of participants in Korea running event, Pearson's product-moment correlation was employed. It was found that most correlation coefficients for factors were .05 , indicating significance. The correlation analysis results are presented in Table 5 .

Table 5. Results of correlation analysis

\begin{tabular}{llllll}
\hline & 1 & 2 & 3 & 4 & 5 \\
\hline Event attitude & 1 & & & & \\
Brand attitude & $.501^{* * *}$ & 1 & & & \\
CSR image & $.294^{* * *}$ & $.267^{* * *}$ & 1 & & \\
Good image of corporation & -.060 & -.068 & $.549^{* * *}$ & 1 & \\
Purchase behavior & $.256^{* * *}$ & $.262^{* * *}$ & $.261^{* * *}$ & .087 & 1 \\
\hline
\end{tabular}

\subsection{Effect of Attitude on Corporate Image of Participants in Korea Running Event}

The result of analysis on effect of attitude on corporate image is as follow. The value of $\mathrm{R}^{2}$ was .099 , which means it explains $9.9 \%$ of total variation. The value of $\mathrm{F}$ was 18.819 , which appeared to be statistically significant. All the sub-factors of attitude revealed a significant and positive effect on event attitude $(\beta=.181)$ and brand attitude $(\beta=.127)$ of corporate image $(p<.001, p<.05)$. Table 6 summarizes results of effect of attitude on corporate image.

Table 6. Results of effect of attitude on corporate image

\begin{tabular}{llllll}
\hline Independent variables & Dependent variables & $\mathrm{B}$ & $\mathrm{SE}$ & $\beta$ & $\mathrm{t}$ \\
\hline Event attitude & Corporate image & .164 & .046 & .181 & $3.564^{* * *}$ \\
Brand attitude & & .123 & .051 & .127 & $2.411^{* * *}$ \\
$\mathrm{R}^{2}=.099$ & Revised $\mathrm{R}^{2}=.089$ & F-value $=18.819^{* * *}$ & & \\
\hline
\end{tabular}

Note. $* * * p<.001$. 
Table 7. Results of effect of attitude on purchase behavior

\begin{tabular}{llllll}
\hline Independent variables & Dependent variables & $\mathrm{B}$ & $\mathrm{SE}$ & $\beta$ & $\mathrm{t}$ \\
\hline Event attitude & Purchase behavior & .132 & .046 & .163 & $2.887^{* * *}$ \\
Brand attitude & & .168 & .051 & .186 & $3.306^{* * *}$ \\
$\mathrm{R}^{2}=.091$ & Revised $\mathrm{R}^{2}=.087$ & F-value $=19.205^{* * *}$ & & \\
\hline
\end{tabular}

\subsection{Effect of Corporate Image on Purchase Behavior of Participants in Korea Running Event}

The result of analysis on effect of corporate on purchase behavior is as follows. The value of $\mathrm{R}^{2}$ was .074 , which means it explains $7.4 \%$ of total variation. The value of $\mathrm{F}$ was 15.192 , which appeared to be statistically significant. One of the sub-factors of corporate image revealed a significant and positive effect on corporate social responsibility image $(\beta=.319)$ of purchase behavior $(\mathrm{p}<.001)$.

Table 8. Results of effect of corporate image on purchase behavior

\begin{tabular}{llllll}
\hline Independent variables & Dependent variables & $\mathrm{B}$ & $\mathrm{SE}$ & $\beta$ & $\mathrm{t}$ \\
\hline Corporate social responsibility image & Purchase behavior & .319 & .061 & .308 & $5.228^{* * *}$ \\
Good image of corporation & & -.085 & .060 & -0.83 & $-1.406^{* * *}$ \\
$\mathrm{R}^{2}=.074$ & Revised $\mathrm{R}^{2}=.071$ & $\mathrm{~F}-$-value $=15.192^{* * *}$ & & \\
Note. & $* * * p<.001$. & & &
\end{tabular}

\section{Discussion and Conclusion}

This study investigated the effects of the attitude toward a title sponsor on corporate image and the purchase intention of a running contest sponsored by a sports enterprise. The results follow.

First, the attitude toward the event and the attitude toward the brand have significant effects on image enhancement and the trust acquisition of the sponsorship effects. Campbell \& Keller (2003) and Holbrook \& Batra (1987) portray advertising effects similarly. To obtain a positive sponsorship effect for the title sponsor from the contestants of the running contest, the participants' attitude toward the event should be formed positively and favorably. The participants in recent running events are of various age groups, running in tiered events: $5 \mathrm{~km}, 10 \mathrm{~km}$, and half marathon. Market segmentation should meet the needs of each group.

Second, attitudes toward the event and the attitudes toward the brand influence purchase behavior. The more positive the attitude toward running events and the brand, the greater the influence on purchase behavior. Laroche, Kim, \& Zhou (1996) report that brand familiarity and positive attitudes affect purchase intentions, indicating that race participants feel positive about the company hosting the event they are participating in (Goldsmith, Lafferty, \& Newell, 2000). For sports brand companies, active marketing should be conducted to check the effects of sponsorship to determine whether they can naturally reach those consumers who avoid advertisements.

Third, an image of corporate social responsibility influenced purchase behavior, but a good image of the corporation did not affect purchase behavior. In a study on the sponsorship effect of Samsung, the official sponsor of the Olympics, Kang, \& Stotlar (2011) report that sponsorship activities positively influence internal and external images of a company. Cornwell \& Coote (2005) also report that corporate participation in sponsorship affects a firm's image. However, in this study, this can be interpreted as meaning that positive attitude shifts in purchase behavior affect companies with an image of social responsibility activity rather than an existing good image. Therefore, while it is important to promote the company and image, it is necessary to highlight the social responsibility image (Maignan \& Ralston, 2002). Sports sponsorship is rapidly growing, companies are increasingly participating in a variety of ways, and related research is actively underway. Study of participatory sports events is relatively limited. Most sports sponsorship research focuses on sports, in particular widely followed (Olympic and international sports events) and professional sports events. Future research should focus on various types of events. It is necessary to present different types of data regarding the active investment of companies. In particular, since running competition in Korea vary by region and sports brand studies should be continuously carried out not only on hosting competitions but also to promote the active attraction of investments. 


\section{References}

Brodie, R. J., Ilic, A., Juric, B., \& Hollebeek, L. (2013). Consumer engagement in a virtual brand community: An exploratory analysis. Journal of Business Research, 66(1), 105-114. https://doi.org/10.1016/j.jbusres.2011.07.029

Burnett, J., \& Hutton, R. B. (2007). New consumers need new brands. Journal of Product \& Brand Management, 16(5), 342-347. https://doi.org/10.1108/10610420710779636

Cakici, N. M., \& Shukla, P. (2017). Country-of-origin misclassification awareness and consumers' behavioral intentions: Moderating roles of consumer affinity, animosity, and product knowledge. International Marketing Review, 34(3), 354-376. https://doi.org/10.1108/imr-08-2015-0178

Campbell, M. C., \& Keller, K. L. (2003). Brand familiarity and advertising repetition effects. Journal of Consumer Research, 30(2), 292-304. https://doi.org/10.1086/376800

Chien, P. M., Cornwell, T. B., \& Pappu, R. (2011). Sponsorship portfolio as a brand-image creation strategy. Journal of Business Research, 64(2), 142-149. https://doi.org/10.1016/j.jbusres.2010.02.010

Cole, S. T., \& Illum, S. F. (2006). Examining the mediating role of festival visitors' satisfaction in the relationship between service quality and behavioral intentions. Journal of Vacation Marketing, 12(2), 160-173. https://doi.org/10.1177/1356766706062156

Cornwell, T. B., \& Coote, L. V. (2005). Corporate sponsorship of a cause: the role of identification in purchase intent. Journal of Business Research, 58(3), 268-276. https://doi.org/10.1016/s0148-2963(03)00135-8

Cornwell, T. B., Humphreys, M. S., Maguire, A. M., Weeks, C. S., \& Tellegen, C. L. (2006). Sponsorship-linked marketing: The role of articulation in memory. Journal of Consumer Research, 33(3), 312-321. https://doi.org/10.1086/508436

Cretu, A. E., \& Brodie, R. J. (2007). The influence of brand image and company reputation where manufacturers market to small firms: A customer value perspective. Industrial Marketing Management, 36(2), 230-240. https://doi.org/10.1016/j.indmarman.2005.08.013

Du, S., Bhattacharya, C. B., \& Sen, S. (2010). Maximizing business returns to corporate social responsibility (CSR): The role of CSR communication. International Journal of Management Reviews, 12(1), 8-19. https://doi.org/10.1111/j.1468-2370.2009.00276.x

Fourie, J., \& Santana-Gallego, M. (2011). The impact of mega-sport events on tourist arrivals. Tourism Management, 32(6), 1364-1370. https://doi.org/10.1016/j.tourman.2011.01.011

Funk, D. C., Mahony, D. F., Nakazawa, M., \& Hirakawa, S. (2001). Development of the sport interest inventory (SII): Implications for measuring unique consumer motives at team sporting events. International Journal of Sports Marketing and Sponsorship, 3(3), 38-63. https://doi.org/10.1108/ijsms-03-03-2001-b005

Gedenk, K., \& Neslin, S. A. (2000). The role of retail promotion in determining future brand loyalty: Its effect on

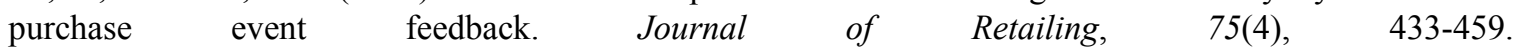
https://doi.org/10.1016/s0022-4359(99)00018-4

Goldsmith, R. E., Lafferty, B. A., \& Newell, S. J. (2000). The impact of corporate credibility and celebrity credibility on consumer reaction to advertisements and brands. Journal of Advertising, 29(3), 43-54. https://doi.org/10.1080/00913367.2000.10673616

Gratton, C., Shibli, S., \& Coleman, R. (2006). The economic impact of major sports events: a review of ten events in the UK. The Sociological Review, 54(2), 41-58. https://doi.org/10.1111/j.1467-954x.2006.00652.x

Gwinner, K., \& Swanson, S. R. (2003). A model of fan identification: Antecedents and sponsorship outcomes. Journal of Services Marketing, 17(3), 275-294. https://doi.org/10.1108/08876040310474828

Hightower, R., Brady, M. K., \& Baker, T. L. (2002). Investigating the role of the physical environment in hedonic service consumption: an exploratory study of sporting events. Journal of Business Research, 55(9), 697-707. https://doi.org/10.1016/s0148-2963(00)00211-3

Holbrook, M. B., \& Batra, R. (1987). Assessing the role of emotions as mediators of consumer responses to advertising. Journal of Consumer Research, 14(3), 404-420. https://doi.org/10.1086/209123

Javalgi, R. G., Traylor, M. B., Gross, A. C., \& Lampman, E. (1994). Awareness of sponsorship and corporate image: An empirical investigation. Journal of Advertising, 23(4), 47-58. https://doi.org/10.1080/00913367.1943.10673458 
Kang, K. J., \& Stotlar, D. (2011). An Investigation of Factors Influencing Decision Making for Participation in the Olympic Partners Sponsorship: A Case Study of Samsung. International Journal of Applied Sports Sciences, 23(1), 225-250. https://doi.org/10.24985/ijass.2011.23.1.225

Ko, Y. J., Chang, Y., Park, C., \& Herbst, F. (2017). Determinants of consumer attitude toward corporate sponsors: A comparison between a profit and nonprofit sport event sponsorship. Journal of Consumer Behaviour, 16(2), 176-186. https://doi.org/10.1002/cb.1622

Laband, D. N., Seals, R. A., \& Wilbrandt, E. J. (2015). On the importance of inequality in politics: duplicate bills and bill co-sponsorship in the US House of Representatives. Economics of Governance, 16(4), 353-378. https://doi.org/10.1007/s10101-015-0170-0

Laroche, M., Kim, C., \& Zhou, L. (1996). Brand familiarity and confidence as determinants of purchase intention: An empirical test in a multiple brand context. Journal of Business Research, 37(2), 115-120. https://doi.org/10.1016/0148-2963(96)00056-2

Maignan, I., \& Ralston, D. A. (2002). Corporate social responsibility in Europe and the US: Insights from businesses' self-presentations. Journal of International Business Studies, 33(3), 497-514. https://doi.org/10.1057/palgrave.jibs.8491028

Marshall, D. W., \& Cook, G. (1992). The corporate (sports) sponsor. International Journal of Advertising, 11(4), 307-324. https://doi.org/10.1080/02650487.1992.11104507

Meenaghan, T. (2001). Sponsorship and advertising: A comparison of consumer perceptions. Psychology and Marketing, 18(2), 191-215. https://doi.org/10.1002/1520-6793(200102)18:2<191::aid-mar1005>3.0.co;2-c

Nguyen, N., \& Leblanc, G. (2001). Corporate image and corporate reputation in customers' retention decisions in services. Journal of Retailing and Consumer Services, 8(4), 227-236. https://doi.org/10.1016/s0969-6989(00)00029-1

Nicholls, J. A., Roslow, S., \& Dublish, S. (1999). Brand recall and brand preference at sponsored golf and tennis $\begin{array}{llll}\text { tournaments. European Journal of } & \text { Marketing, 33(3/4), }\end{array}$ https://doi.org/10.1108/03090569910253198

Rowley, J., \& Williams, C. (2008). The impact of brand sponsorship of music festivals. Marketing Intelligence \& Planning, 26(7), 781-792. https://doi.org/10.1108/02634500810916717

Roy, D. P., \& Cornwell, T. B. (2004). The effects of consumer knowledge on responses to event sponsorships. Psychology \& Marketing, 2l(3), 185-207. https://doi.org/10.1002/mar.20001

Sharma, N., \& Patterson, P. G. (1999). The impact of communication effectiveness and service quality on relationship commitment in consumer, professional services. Journal of Services Marketing, 13(2), 151-170. https://doi.org/10.1108/08876049910266059

Smith, G. (2004). Brand image transfer through sponsorship: A consumer learning perspective. Journal of Marketing Management, 20(3), 457-474. https://doi.org/10.1362/026725704323080498

Stipp, H., \& Schiavone, N. P. (1996). Modeling the impact of Olympic sponsorship on corporate image. Journal of Advertising Research, 36(4), 22-28. https://doi.org/10.1080/02650487.1998.11104706

Wohlfeil, M., \& Whelan, S. (2006). Consumer motivations to participate in event-marketing strategies. Journal of Marketing Management, 22(5), 643-669. https://doi.org/10.1362/026725706777978677

\section{Copyrights}

Copyright for this article is retained by the author, with first publication rights granted to the journal.

This is an open-access article distributed under the terms and conditions of the Creative Commons Attribution license (http://creativecommons.org/licenses/by/4.0/). 